University of Louisville

ThinkIR: The University of Louisville's Institutional Repository

Electronic Theses and Dissertations

1947

\title{
Education for family living.
}

Dorothy Moran

University of Louisville

Follow this and additional works at: https://ir.library.louisville.edu/etd

Part of the Education Commons

\section{Recommended Citation}

Moran, Dorothy, "Education for family living." (1947). Electronic Theses and Dissertations. Paper 2057. https://doi.org/10.18297/etd/2057

This Master's Thesis is brought to you for free and open access by ThinkIR: The University of Louisville's Institutional Repository. It has been accepted for inclusion in Electronic Theses and Dissertations by an authorized administrator of ThinkIR: The University of Louisville's Institutional Repository. This title appears here courtesy of the author, who has retained all other copyrights. For more information, please contact thinkir@louisville.edu. 


\title{
UNIVERSITY OF IOUISVIIIE
}

EDUCATION FOR FANILY LIVING

\author{
4. Professional Paper Submitted \\ to the Faculty of the Graduate School \\ of the University of Louisville
}

In Partial Fulfillment of the Requirements for the Degree of Master in Education

\section{Department of Education}

$$
\text { by }
$$

Dorathy Noran 
NANE OF STUDENT:

Dorothy Moran

TITIE OF PROFESSIONAL PAPER: EDUCATION FOR FANILY LIVIIG

APPROVED BY READTNG CONITTEE COVPOSED OF THE FOLLOWING NEMBER:

Ruth Mitchell

Hilda Threlkeld

J. J. Oppenheimer

NANE OF DIRECTOR:1, B. Noe

DATE: $\frac{0 \text { an; } 10,1948}{0}$ 
EDUCATION FOR FAMILY IIVING 
TABLE OF CONTENTS 
TABIE OF CONTENTS

Page

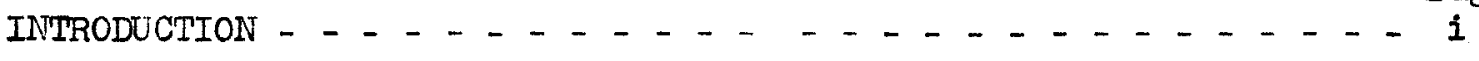

SECTION

I. CHANGING PATTERNS IN FARILY LIFE $\ldots \ldots \ldots$

II. BEGINNIINGS OF FANILY LIFE EDUCATION

IN HONE ECONONIICS COURSES _ $\ldots \ldots \ldots$

III. STUDIES IN FANILY IIFE AND FANILY LIFE

EDUCATION IN RECENT YEARS - . . . . . . . . . 7

IV. SUGGESTIONS FOR FANILY LIFE EDUCATION

WITH EMPHASIS ON ITS PLACE IN THE

HONE ECONONICS FIEID _ - . $\ldots \ldots$ 
INTRODUCTION 
It is widely felt that our schools are not adequately preparing the youth of today for the most vital part of his existence as a member of a family group. No matter what profession or work he may choose or follow, no matter whether he is rich or poor, he is still a part of a family group. As an intelligent and understanding nember of that group, he can do much for his own happiness and much for those about him.

Until a few years ago courses in homenaking and family living were designed entirely for girls and women through courses in home economics. Today educators see the importance of courses adapted to the needs of boys and young men of high school and college level in courses in marriage and family relationships. In fact, educators of today feel that education for living should begin in the early years of the elenentary school, so the ehild can learn to understand his own fears and emotions. If these are brought freely into open discussion, they are not likely to become repressions. The child then realizes that other children have the same feelings, the same emotions that are natural to all.

Democracy begins in the home. The home must recognize and conserve human values and respect personalities. Sane, emotionally mature personalities are developed in the home. The ways of democratic living are centered in the home. An immediate contact with other individuals of the family in our early years is our first contact with society; later these contacts broaden out to the neighborhood, the community, the state, and the nation. If we live in the democratic way in our family, we can better understand cooperation with others outside our family as our horizons widen. 
The child in the early years needs the feeling of belonging, needs affection and understanding, and the feeling of security. If he lacks these in his early years, he may always lack that sense of security that is so important to normal development. Complexes of inferiority and unsureness may then follow him through life.

What we as educators can do to promote better understanding within the family to prevent future broken marriages and broken homes, what we as educators can do to inculcate tolerance wi thin the family group, and consequently tolerance outside it are vital problems. Making happy and well integrated personelities of those who come under our guidance should be our goal. 
SECTION I

CHANGIHG PATTERINS IN FANIIIY IIFE 


\section{CHANGING PATTERISS IN FANIIIY LIFE}

The status of the family is constantly changing as can be realized if one studies family life through successive generations. These changes uslially have been gradual, but at times changes have been suddenly brought about. At one time the family was an industrial and economic unit-not dependent on society for its way of life. A man's work and his leisure, and that of his family were centered in his home. Growth of industry, inventions, transportation, and cormunications brought about changes in his way of life. The family howerer is still the core of his existence, even though many of the earlier functions of the home have moved out into wider areas, and though he is today more dependent on outside sources in making a living and in finding his amsements.

Recent studies show an enormous increase in the divorce rate--an increase that has swung up sharply since the war years. Many theories have been advanced concerning the cause of this trend. Hasty marriages of people with different cultural background and experiences have increased during the war years. The difficulties of readjustment after long, enforced separation at the time when adjustments to each other would normally take place with a young married couple have added to causes of marriage difficulties. Each of the two in these years of separation has been experiencing different ways of living which may have widened the already existing differences. Many children have been without their fathers at a crucial time of their growth and development.

The financial and housing situations, still deplorable, are changing the pattern of normal family living. Young couples who formerly would have 
had a home of their own in which to adjust to each other, to make a way of life, have been denied that opportunity, and if we can predict the results we can see a disintegration of families that normally could have worked out in a different pattern.

The increase in numbers of women in industry is another factor in the increased divorce rate. Women have grown more independent financially, and the homes and the children have suffered. The ties of the family have been loosened with the woman's interests being divided between her home and her work.

Tolerance toward divorce has grown both in social and religious groups, so that too has brought on an increase in divorces.

Divorce, howerer, is only a concrete evidence of the dissatisfactions oceurring in family life. There are tensions existing which are reflected in the child's growth and development, tensions which we know exist but which are not easily measured or put forward statistically. Observations of family relationships are difficult because the more subtle aspects of family life and affairs within the family are not easily observed. Many of these madjustments within the family are brought into our focus in the schools through the child and his actions. In a recent article Mr. Harry Harmsworth expresses from the sociologist's view point that in spite of postwar tensions, expressed in terms of mental ability, the family is still recognized as the primary group. The social mores rest in the home; attitudes and behavior problems are born in the home, and there emotions find expression. Beyond the home, informal groups and neighborhood groups are also a source of primary relationships. An individual's 
approach to his social problems is through these primary groups. I

What have the perplexing problems of the family to do with school

and education? As the family patterns have changed, training and educa-

tion in the home have decreased. The schools have a growine responsibility

to promote better family understanding, a responsibility to develop in the

child an emotionally adjusted personality, so he can understand his part

in the family and the social group. In the development of such personali-

ties we can make for a better social order, a better democracy.

In the book Family Living In Our Schools is given a basic philosophy

for home and family living.

"Namely how to make men and women conscious of the treasures that are offered in daily life-horemaking, bearing and rearing children, living together--which now they do not fully sense or may even destroy because they are blind and unaware, or preoccupied with other activities and interests. Our ethical and normal aspirations have so long been directed to extra human goals and purposes, without appreciation for the richness and meaning of daily life and the primary significance of human relations, trat today we must consciously and deliberately attempt to recapture a capacity for living. ParticularIy in the light of the challenges of today, we need new courage and faith that life itself has value and meaning if we can bring to it capacities for living and hoping, and an awareness of the treasures to be gained through warm affectionate relationships, especially within the family.

"An education addressed to these poignant hopes and aspirations can bring that nech needed courage and faith if it will speak with sincerity about these personel concerns and vital longings. An education which would limit itself to the bare teaching of facts and scientific knowledge and insist on objectivity could offer little of value to perplexed individuals who already know most of the so called "answers" but haven't the emotional conriction necessary to translate knowledge into daily living.

1. Harmsworth, Harry, "Primary Group Relationships in Modern Society", Sociology and Social Research, Narch - April, 1947, p. 291. 
Today more than ever children and young people, men and women need the wise counsel and mature advice of others to help work out their aspirations and longings in terms of actual ways of ljving -- of working, playing, feeling, and enjoying."

The individual, and the family are the core of our democracy of today. If we want a democratic social order each individual must help in achieving it.
"The home is not only a place where democracy begins but within the family we may say that the issue of democracy must be faced anew in each generation. We cannot hope for a decent, orderly society that recognizes and conserves human personality and destroys the dignity of any of its members, since they will de- structively react on society. For a democratic society, then it becomes clear that we must have sane, integrated, emotionally mature personalities who find in living. especially in married and family life, worthwhile goals and opportunities and so are able to create and maintain a democratic society dedicated to human values. ${ }^{2}$

The schools of America can do a better job in educating young people for a better life by developing in them an emotional maturity that will help them in the decisions they are meeting now and that will confront them as adults in the complex world of today.

1. Family Living and Our Schools, Joint Committee on Curriculum Aspects of Education for Home and Family Living, New York: D. Appleton Century Co., 1941, p. I.

2. Ibid., p. 6 . 
SECTION II

BEGINNINGS OF FAMIIY IIFE EDUCATION IN HORE ECONORICS COURSES 


\section{BEGINNINGS OF FANILY LIFE EDUCATION}

IN HONE ECONOMICS

Family life education had its beginnings in the school ourriculum in home economics courses offered for the most part in grades seven through twelve. Eren though the scope of these courses has widened enormously in the last twenty years, beyond the skills in cooking, sewing, and home management, they do not suffice in supplying the real needs for family living for several apparent reasons:

1. Except for one or two years at the junior high school level these are not required courses.

2. Except in very few instances home economics courses are offered only to girls.

3. Much emphasis is still placed on the skills of home making.

The deficiencies of our present program of fanily life education in the high school are shown in The American High School, the Eighth Year Book of the John Dewey Society. As suggestions are given for a program of education, they show a lack of a well integrated program at the present time.

"All youth are members of families and a large majority will establish homes. In the later years of high school they generally become concerned with matters that are basic to the establishment of homes. All too often extreme interest in the opposite sex is dismissed as an unfortunate interference with education. This interest is usually indicative of a readiness for guidance and help in the basic area of family life. It should be seized upon as an important area of emphasis in the core program. 
"In the usual high school program a small fraction

of the student body receives any instruction relating

to family Iife. Too often only girls are reached and the dominant activities, in spite of major emphasis in modern theory of home economics to the contrary, are cooking and sewing. The result is that an area of cormon need is dealt with very inadequately. By including this in the core program an opportunity is afforded to provide all youth certain basic experiences relating to family life. Understanding the importance of the family in our soeiety, sensing problems to be met in effective family relationships, improving the effectiveness of their own family participation, and developing of appropriate attitudes toward the opposite sex, leading toward eventual mate selection and hore establishment, all are possible growth areas."

Thus, inclusion of family life is given equal importance with other areas such as socio-civic competence, work, and health.

1. Caswell, Hollis, Editor, American High School, Eighth Year Book of the John Dewey Society, New York: Harper Bros., 1946, p. 147 . 
SECTION III

STUDIES IN FANILY LIFE AND FANILY LIFE EDUCATION IN RECENT YEARS 
The interest in family life education has been growing in the past decade. This interest shows a realization of the need in general education for the inculcation of family life study and its related subjects.

That the need is ever present appears to be clear to educators, sociologists, and psychologists, in fact to all who deal with individuals and their families. What is not clear is the approach and content of the subject matter to be presented.

The consensus of opinion seems to be that the schools have failed in the pest to produce individuals who are prepared to meet situatiors in adult life with a sound emotional and mature outlook. That life today is more complex than in the past and that the problems that must be faced are more difficult and numerous, are accepted facts. Studies In the last few years give evidence of the interest and effort of leaders in the field of education.

The American Association of School Administrators chose Education for Family Iife as the topic of its Nineteenth Year Book published in 1941. This study showed an awakened interest in the family and the realjzation of the schools obligations to the homes of America. In the same year a joint committee of the Home Economics Department of the National Education Association and the Society for Curriculum Study published Family Living and Our Schools as a result of their research.

The following statements are taken from the forerords of the two publications. 


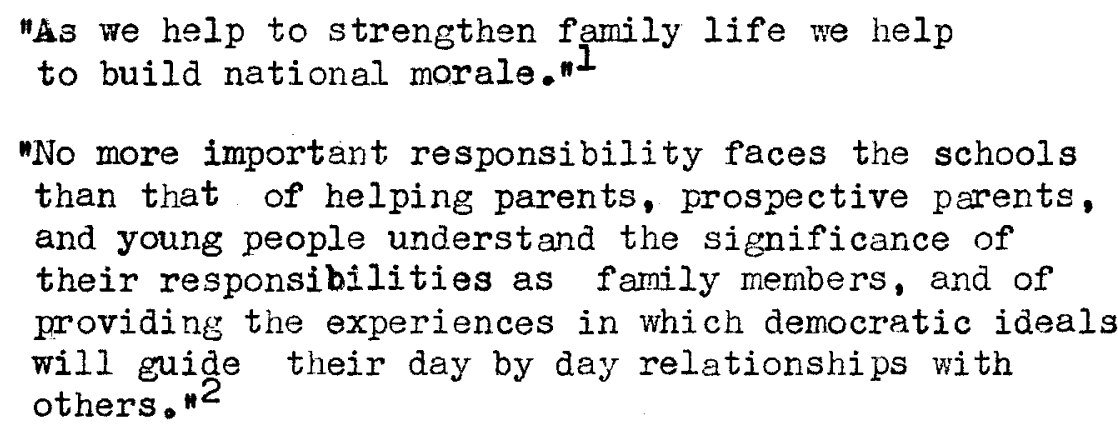

The scope of these two studies and other more recent ones related to the subject at hand, brought together on the next pages will show some of the research done in the field of family living as a part of the educational program. The more general studies are discussed to show the inclusion of education for family life in the curriculum of the schools of today and tomorrow.

1. Education for Family Life, Nineteenth Year Book, Washington, D. C.1 American Association of 3chool Administrators, 1941, p. 6.

2. Family Living and Our Schools, Joint Committee on Curriculum Aspects of Education for Home and Family Living. New York: D. Appleton Century Co., 1941, p. v. 


\section{EDUCATION FOR FAMILY LIFE}

This study evaluates the real worth of the family in the terms of the needs of the individual and the needs of society. The family is in the process of adaptation to changing civilization and requires all the help education can give. The home because of its problems is in need of help. The study also gives concrete suggestions for programs within the school, and reviews types of programs in existence at the time. It stresses the importarce of assisting adolescents meet the problems of personal adjustment.

The following practical proposals for the consideration of every superintendent and his staff are given.

"1. That the school in its program and practice shal] recognize and respect the developing personality of the indiridual as well as the needs of society and give guidanco to the home in the same direction."

12. That the school at every point shall take the home into account as a coordinate educational agent, a partner, whose cooperation is not only desirable but necessary."

13. That the content of the elementary curriculum as jt becomes integrated around social studies shall include the family as a basic social institution."

"4. That the secondary program which increasingly is being adapted to the needs of adolescent boys and girls shall make specific and adequate provision for their present and future needs as members of families."

"5. That the adult education program as it expands for the good of the community shall assume responsibility for helping husbands and wives, fathers and mothers, as they strive to make the American hone realize its fullest possibijities." I

1. Education for Family Life, Nineteenth Year Book, Washington D. C.: American Association of School Administrators, 194l, p.13. 


\section{FANIIY LIVING AND OUR SCHOOLS}

This study brings out the need for family life education through out the school prograrn and gives suggestions for its incorporation at elementary and high school levels.

It does not suggest definite courses in the grade school; instead it suggests that the content can be found in all phases of the elementary school program, for example, in games, in hobbies, in stories, in the consideration of types of food that make a balanced diet. It stresses the importance of the cooperation of the parent.

At the secondary level many descriptions of practices are given. Schools which have core programs are described in relation to their instruction in family living. In schools that have traditional subject matter courses there is evidence that the emphasis has been changed and the courses have been reorganized to give consideration to the pupils' needs in relation to home living. (The comittees feel that there is still much to be done in assisting the pupils to a clearer understanding of thernselves and their problems). Some schools have organized special courses in home and family living. One of the many samples given is a summary of a course in Senior Problems offered in the high schools of Los Angeles. This course is required of all the pupils. It was developed by teachers with various subject matter backgrounds and includes consumer economics, social arts, family relations, and relations with the community. The units that are generally taught are as follows

"Consumer economics includes, Better buymanship, food, clothing, drugs, cosmetics, housshold equipment; techniques of buying, reading labels, analysis of ralues, when and where to buy; use of credit, charge accounts, installment buying, borrowing, budgeting; frauds and their detection; aids to consumer, Government, private cooperation. 
"Social arts includes: the home as a background for the individual; how family activities contribute to successful home; the home as a center for entertaining friends; manners and convertions of social life.

"Family relationships includes: learning about ourselves and heredity eugenies; elementary psychology; getting along with ourselves and others; institution of marriage; preparation for marriage, personality problems, courtship, choosing a mate, requirements for successful marriage, law and the family; relationships within the family.

"Relations with. the cormunity includes a choice from the following groups. Vocational orientation fundamental attitudes, self-analysis and self-appraisal, application for jobs, technique of the interview, opportunities for further trairing, job analysis. Educational orientation opportunities; study of catalogue, types of courses, requirements. Leisure resources of the community philosophy of leisure, motion picture appreciation, radio, theater."I

1. Family Living and Our Schools, Joint Committee on Curriculum Aspects of Education for Home and Family Iiving. New York: Appleton Century Co., 194l, p. 177 . 
This book deals with the development of the secondary school through the past century. It shows the growth of high schools in numbers and in scope, the changes in objectives developed because of changes in the nature of the student body.

In the surmary of objectives the following points are called to the reader's attention.

Notice how certain goals and purposes remain constant through many statements of objectives from Spencerl to the present. -...... "There is only minor emphasis, so far as secondary schooling is concerned, upon the objectives of producing the scholar but greater emphasis on producing persons." 2

In the study of the core programs in the schools the emphasis on personality development and adjustment, family living and social living, seems to be similar in this text as in other studies of present day education.

1. Herbert Spencer's statements (around 1850)

"To prepare us for complete living is the function which education has to discharge. It behooves us to set before ourselves, and ever so elearly keep in view, complete living as the end to be acheived; so that in bringing up our children we may choose subjects and methods of instruction, with deliberate methods to this end."

2. Williams, L. A., Secondary Schools for American Youth, New York: American Book Co., 1944. p. 185. 
PLANIING FOR ANERICAN YOUTH

This study which is a summary of Education for Ail American Youth deals with all phases of high school education for both mural and urban corminuities. It presents brief and graphic descriptions of examples of secondary school programs for each in the jost war world.

In the section "The Secondary Schools Flave Developed Courges in Cormon Learning to Make Good Citizens of Girls and Boys," the following learnings in the unified courses are offered. These courses are designed to meet three of the Imperative Needs of Youth.

1. Their need to grow in understanding and in competent performance of their obligations as members of the community, state, and nation.

2. Their need to grow in skills, knowledge of social and ethical principles involved in their relations with other people, particularly in family life.

"3. Their need to grow in the understanding of democratic principles, in their application of the scientific method, and in the acceptance of the values basic to our civilization."I

Although the general purposes are plarined in advance, the pupils also assist in planning the details of the courses. Planning for American Youth is not a study based primarily on education for family life. It takes the high school as a whole, and gives an over-view of all the learnings needed for American youth. This study, however, includes understanding of self and family as one of the basic needs of all individuals.

1. Flanning for American Youth, Washington, D. C.l National Association of Secondary School Principals, 1944, p. 43.

Note: Flannirig for American Youth is a pjctorial summary of the study Education for All American Youth, Washington, D. C.: Education Policies Commission, National Fducational Association and American Association of School Administrators. 
THE ANERICAN HIGH SCHOOL

ITS RESPONSIBIIITY AND OPPORTUNITY

The committee responsible for this study gives as the purpose of its year book, the analyzing of the needs and status of American youth and the contribution which the high school can make to their education and successful transition to adult life.

A few thought provoking questions from the chapter by MI. Paul Leonard are quoted.

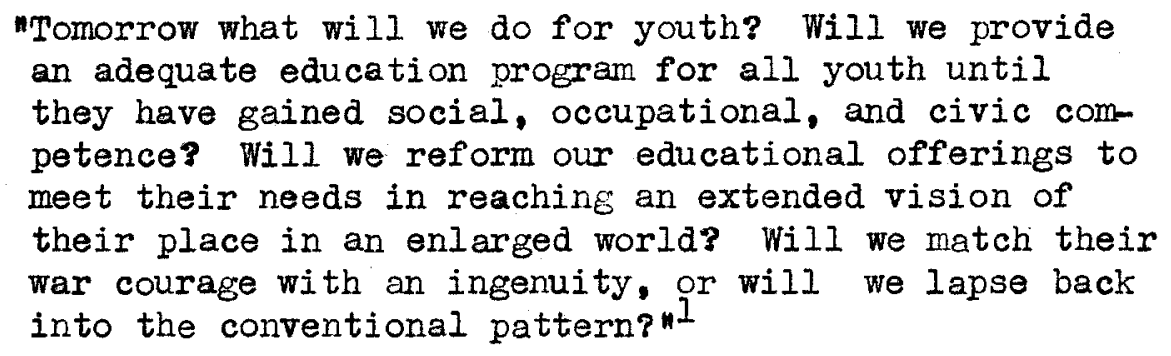

Mir. Gordon Mackenzie in The American High School raises eight current issues in respect to secondary education, that he says mist be resolved as the future of the American high schools depends on how they are settled. They are as follows:

"I. Will free public secondary education be provided for all youth?

"2. Will high schools provide education for the common life?

"3. Will schools provide vocational orientation and preparation?

"4. Will secondary education provide opportunity for personal and social advancenent?

"5. Should high schools become custodial agencies?

1. Caswell, Hollis, Editor, The American High School, Eighth Year Book of John Dewey Society, New York: Harper Bros., 1946, p. 30. 
"6. Should secondary education assist in modifying the culture?

17. Should high schools become community educational centers?

18. What should be the pattern of organization for secondary education?"I

This study attempts to analyze conditions and problems of the existing high schools, and gives curriculum proposals for the future.

1. Caswell, Hollis, Editor, The American High School, Eighth Year Book of John Dewey Society, New York: Harper Bros., 1946, p. 30. 
THE HIGH SCHOOL CURRICULUN

This study is more practical than many of the new ones as it covers the trends in subject matter fields and gives suggestions for improvement in each field to bring it closer to the needs of the individual in the adjustment to the present and the future.

In the chapter "Nature and Function of the Curriculum" the purpose of education is sumnarized.

"It is the purpose of education to so stimulate and guide the growth of the individual that he will function in certain areas and activities of life upon which there is fairly general agreenent among: the careful students of education. Vocation, home citizenship, an enjoyment of leisure----and to possess in high degree mental and physical health and vigor, and the skills and interests appropriate to most effective learning in the future." 1

Since the curriculum based on subject matter fields is still more largely practiced than the core curriculum, it is important for administrators and teachers to attempt to enrich each field and to understand how subject fields can be correlated to aid the individual. Helpful suggestions for such correlation may be found in this study.

From the chapter "Personal and Family Living in the Curriculum", one statement is quoted here to sum up the objectives suggested in that field.

"A functioning curriculum will provide for educational experiences which will help individuals to make the necessary immediate adjustments and which at the same time will help them set up important long time values to guide future family living." 2

Practical suggestions are given for the home economics teacher in her teaching of family problems. Suggestions are offered for the correlation of home economics with other fields within the school.

1. Douglas, Harl R., The High School Curriculum, New York: Ronald Press Co., 1947, p. 32. 
SEX EDUCATION IN HIGH SCHOOL

Sex education is another debatable problem. It seems to be generalIy agreed that 'sex education' is a necessary part of the school program, but how it is to be taught is stjll a question that has not beer answered. Nany educators feel that sex education should be incorporated naturally within other fields of study such as health, mental hygiene, biology, and physiology, social studies and hone economics, all of which have a part in the students' education for successful living.

Sex Education in High Schools by John Newton Baker ${ }^{l}$ presents to us the need for sex education in the high schools. The author suggests courses in marriage as an excellent media for sex education. He emphasizes the importance of sex education for girls as a part of the regular curricuIum in the secondary schools because girls mature earlier than boys.

The scope of the attention and opposition to sex education in the high schools is given from parents, from religious groups, and from the schools themselves. The incorporation of sex education in biology, in sociology, in physical education, and in other fields is discussed with the advantage and the disadvantage of each. Concerning the intecration of sex education in home economics, it is conceded that the advantages are the informality which permits contact between teacher and student and the segregation of sexes, the disadvantages are that with few exceptions there is no comparable class for boys, and secondly that home economics classes have the tendency to deal with "home managernent" rather than "home making". outlines of a few courses in sex education offered in the jears 1939-1940 in American high schools are given.

\footnotetext{
1. Baker, John Newton, Sex Education in High Schools, New York Emerson Books, Inc., 1943.
} 


\section{BRIEF REVIEWS OF OTHER STUDIES REIATING \\ TO EDUCATION FOR FAMILY LIFE}

\section{MODERN HIGH SCHOOL CURRICULUN}

This is a survey of the Illinois high schools, the curriculum and practices observed. Each subject field is discussed in separate chapters, giving the practices at the time with suggestions for improvement. There is also shown possible correlation between subjects, how subjeats of study may be interwoven and thus made more significant.

In relation to homemaking and home economics, the following paragraph is quoted here.
Miany of the other subjects of study have some con- tribution for homemaking. English should function in leisure time reading, in the fine art of con- versation, and in the selecting of library books, magazines, and bulletins; the social studies in furnishing an understanding of the world today; business education in budgeting, accounting, consumer buying, and advertising; health and physical education in providing a strong body and a knowledge of and a will to maintain it so."l

\section{MENTAL HEALTH IN THE CLASSROON²}

Samples of investigations from various sciences, which justify a faith in mental hygiene in modern education, are given. Studies of the fundamental needs of the child, his physical and mental development, and his relationships to the family and community are analyzed.

Mental bealth is given an equal importance with physical health in the development of the child.

1. Belting, Paul E. and Natalie M., Nodern High School Gurriculum Champaign. Ill.: The Gerard Press, 1942, p. 261.

2. Mental Health in the Classroom. Thirteenth Year Bcok of Supervisors and Directors of Instruction of The National Education Association. Washington, D. C.: National Education Association, 1940. 


\section{YOUR MARRIAGE AND FANILY IIVING ${ }^{1}$}

Mr. Landis's new book deals with personal problems of young people from dating through courtship to marriage and family life. It gives the historical background of the American family which shows that marriage and the family are of social as well as personal importance. This text should be of assistance to high school students. It offers many references for both students and teachers.

\section{EDUCATION FOR TODAY AND TOMORROW ${ }^{2}$}

Nr. Reeves in his suggestions for revisions in the educational program stresses the importance of educetion for citizenship, education for physical and mental health, and education for reading, and for successful famijgr life.

In turning toward the questions of mental problems, the family and the home, Mr. Reeves comments on the changing conditions, economic, social, and moral, that surround marriage and successful family living, changes that have been revolutionary. He states that it is not surprising that youth is troubled about marital and parsonal questions and in need of both positive guidance and instruction.

1. Landis, Paul, Your Miarriage and Family Living, New York: MicGraw Hill Book Co., 1946.

2. Reeves, Floyd, Education for Today and Tomorron, Cambridge, Mass.: Harvard University Press, 1946. 
SECTION IV

SUGGESTIONS FOR FANIIY IIFE EDUCATION WITH ENPHASIS

ON ITS PLACE IN THE HONE ECONOMICS FIELD 


\section{SUGGESTIONS FOR FAVILY LIFE EDUCATION \\ WITH EIIPHASIS ON \\ ITS PLACE IN THE HONE ECONONICS FIELD}

Recent books on secondary education seem to emphasize the same general trend. The number of studies that lean toward the core curriculum or general education and the breaking away from traditional subject divisions might be explained by the newress of the plans. Education, as such, is still in its experimental stage. Whether or not the new ideas of curriculum building will prove to be better for the youth of today is still a matter for conjecture. It would be interesting if more of the so-called traditionalists amone the educators would put forth their ideas. The fact that subject matter divisions are still more prevalent in the schnols of Anerica can be taken as an argument in their favor, or as an evidence of educational lag.

In studying new developments in curriculum planning, we can see that many of the ideas of the core curriculum have been absorbed and many subject matter courses have been broadened to bring them closer to the needs of the students. The trend in method is towara more pupil participation and toward more informal classroom procedure, particularly in the field of English and in social studies. Home economics courses have been broadened to include mach more than skills of cooking and sewing. This trend allows for more life like situations and affords opportunity for cooperation of students with each other.

Swinging too far toward what young people want is dangerous. The more experienced teachers and administrators need to hold the reins, and 
mach can be said for discipline as a principal guiding factor in the education of youth.

Wuch that is good can be lost by the breaking down of subjects as such. Although education for living is essential, an understanding of the past which has brought about our civilization of today is of great importance, and certain factual knowledge is necessary for this understanding. A balance between the old and the new rust be reached. Family life education as a basis for living with our families and in our social group is a vital factor. How such a part of the whole education cen best be incorporated in the curriculum is a debatable question. Nuch can be included in the fields of social studies, health, science, and English, and even more directly in the home economics field. Mr. Floyd Reeves in discussing the need of guidance in family study of marital and personal problems raises two questions.

"Are personal and family problems appropriate subjects for secondary school instruction? And if they are, can teachers that are wise and competent to deal with them be found by the average secondary school? I shall try to make my answer to both questions as concrete as possible.

"Child care is certainly a subject which is teachable and is now being widely taught in home-managenent and home economics courses. It should be taught I believe, throughout our secordary schools, and taught to boys as well as girls. Consumer's guidance is a subject appropriate for classroom instruction and is the key to the management of a modern successful home....... ......It is possible to reduce the findings of science on mental health and emotional adjustments to a workable form for secondary school instruction. These subjects as well as the practical techniques of cooking, which are now taught in home economics courses are appropriate for every secondary school. They help to provide young people with some of the tools and techniques for the working out of family problems. But clearly this does not fully go to the heart of the problem that greatly troubles many teachers and parents. There 
remain obviously fields where more intimate guidance is needed when classroom discussion is undesirable, or where wise and competent teachers cannot be found. What is the answer? Here I think is a very practical one. Provide reading naterials. There is a great deal of excellent irstructional material in reading form on personal and family problems."I

In the discussion of practices and plans for the future of home economics in Modern High School Curriculum, it is stated that

"The new curriculum in horne economics mist be designed in such a way that it will function in the present day life of the pupil and provide for the continuous growth of the individual through constant developing experiences. It must enable her to acquir not only skill and information but also right attitudes, good habits, ideals of health, citizenship, work, and leisure. Nore specifically the aims may be outlined as these:

1. To stimulate an interest in homemakine.

2. To give an appreciation that the economic and social relations of family life have a definite influence on the community.

3. Appreciation of the number of processes involved.

4. To teach an appreciation of the labor and skill required in the household.

5. To teach the relation of food to health.

6. To teach a knowledge of what constitutes well planned meals.

7. To give an appreciation of desirable ways to use leisure time in the home.

8. To teach the principles of suitability, selection and care of clothing.

9. To waiken an interest in textiles and home furnishings.

I0. To develop an ability to evaluate guides which most consumers use in selection of goods.

a. The ability to recognize the limitations of inspection, tests, advertising, price.

b. The ability to recognize the possibilities of experiences guarantees, trade marks or brands,

1. Reeves, Floyd, Edication for Today and Tomorrow, Cambridge, Mass . Harvard University Press, 1942, p. 33. 


$$
\text { labels, salesperson, dealer."1 }
$$

Home economias, as it is planned for today is still a field geared to the needs of girls. The elphasis will have to be considerably changed if it is to include the teaching of bors. As the studies reveal the scattered prograns in home economies that offer elucation of any sort to boys in the secondary school are usually special colrses in 'Social Iiving', 'Personality Ad justment' or some similarly named course.

Considering then hore economics as a program for the improvement of home living for girls, the first consideration should be the objectives of such education.

In reviewing commonly existing curricula of secondary schools, it is seen that horne economics education includes the subject matter divisions frequently labeled foods, clothing, home management, consumer problems, home living or social living, child care, and family problems. In other schools some of these are merely units of work included in a broader course sometimes called home economics.

A. general objective of all home economics teaching can be briefly stated as the improvement of family life. As a matter of interest to the teacher of home economics several courses in the hone economics fjeld are outlined here.

\section{I}

PERSONAI AND SOCIAI LIVING ${ }^{2}$

Introduction

(For boys and girls)

1. Surveys of jobs of the community open to high school students for part time work.

1. Belting, Paul E. and Natalie M., Modern High School Curriculum, New York: Gerard Press, 1942, p. 102.

2. Brown, Sarah Ann, "Course in Relationships" Cedar Rapids, Iowa, Journal of Home Economias, 351461, December, 1943. 
2. Study of time required for extra curricular activities.

3. Home responsibilities and tensions caused by students working.

4. Finarcial resporsibilities they should have.

Objectives

1. Realization that successful fanily life is the result of conscious effort and intelligent behavior.

2. Ability to formulate sound generalizations and and apply them to personal and family living.

3. Understanding of the relationship of the individual and his family to the community.

4. Effective participation in group discussion.

5. Realization that a desirable character can be developed only through living with others, taking an interest in them and respecting their personalities, ana maintaining ones' own ideals.

6. Appreciation of the value of a sound philosophy of life.

Procedure or means of fullfilling objectives.

1. Field trips.

2. Reports of student observations of behavior of adolescents, adults, and children.

3. Class surveys.

4. Movies, bulletin board displays, and exhibits.

5. Reference reading.

6. Discussions.

7. Panel discussions.

\section{II}

GOOD BUYMANSHIP

(Unit for a clothing class) ${ }^{1}$

Outline

1. Discussed buying habits

2. Studied advertising

3. Studied labeling and labeling laws

4. Analysis of shopping failures

5. Set up standards for buying various articles

6. Study of fabrics and construction

7. Care of fabrics and other articles.

1. Browne, M. Hazel, "Teaching Good Buymanship in High School", Nyach High School, Njach, N. Y., Journal of Home Economics, 35:142, March, 1943. 
In conclusion of this sumnary, suegestions for a course in Home Iiving or Fanily Living are offered which would incorporate ir its objectives -

1. An understanding of self in relation to others in the family and in the social group

2. The development of an emotionally nature personality

3. An appreciation of family life as a basis fox socieiy

4. knowledge of the part the communty, state and nation play in family life

5. An understanding of the part heredity plays in life

6. An understanding of the influence of the environnent on the individual

7. An apureciation of beauty in our environment

8. knowledge of child developruent and care

9. An appreciation of the importance of physical and mental health

10. knowledge of consuner problems and money menagement

11. An understanding of leisure time activities and their importance in living.

A course based on these objectives could be offered for girls for a

full year in the eleventh and twelfth grades.

To meet the preceding objectives many units of work would have to be planned. In some cases one unit of work would deal with several objectives, in others definite units might accomplish an end to one objective. In planning a program to meet these objectives, there might be cited here a few units of work. For instance the objective stated above knowledge of the part community, state and nation play in family life would involve

\footnotetext{
Note: At present a similar course with a slightly smaller scope is offered for one term in the Girls' High School of Louisville.
} 
laws and customs that regulate marriage and divorce, opportunity for education and recreation that the comminity offers, and protection for health and safety regulated by city or state. An appreciation of beauty in our environment could be brought about by the study of architecture of our homes and of interior decoration. An understanding of the influences of the environment would involve the housing situation, standards of housing for comfort and health, types of homes that lead to physical as well as mental and moral health. 


\section{BIBIJOGRAPHY}

\section{A. BOOKS}

Arlitt, Ada Hart, Family Relationships, New York. MeGraw Hill Co., 1942.

Baker, John Newton, Sex Education in the High School, New York: Emerson Books, Inc., 1943.

Belting, Paul E. and Natalie M., Modern High School Curriculum Champaign: The Gerard Press, 1942.

Berksen, I. B., Education Faces the Future, New York: Harper Bros., 1943.

Dennis, L. T., Living Together in the Family, Washington, D. C.: American Home Economics Association, 1934.

Douglas, Harl, The High School Curriculum, New Yorki Ronald Press Co., 1947.

Drane, Donald, The Needs of Youth, New York: Teachers College Columbia University, 1942.

Education for All American Youth, Educational Policies Conmission, Washington, D. C.: National Educational Association, 1944 .

Education for Family Life, Nineteenth Year Book, American Association of School Administrators, Washinoton, D. C.: American Association of School Aidministrators, 1941.

Encyclopedia of Educational Research, edited by Walter Monroe, New York: McMillan Co., 1941.

Exploring the Curriculum, The Work of Thirty Schools from the Viewpoint of Curriculum Consultants, Edited by Giles, H. H., McCutchens, Zecheil. New Yorks Harper Bros., 1942.

Family Living in Our Schools, Joint Committee of Curriculum Aspects of Education for Home and Family Living, Goodykoontz, Bess and Coon, Beulah I., Co-chairman, New York: D. Appleton Century Co., 1941.

General Education in the American High School, North Central Association of Colleges and Secondary Schools, Chicago: Scott Foresman \& Co., 1942. 
General Education in a Free Society, Harvard Committee, Cambridge: Harvard University Press, 1945.

Hook, Sidney, Education for Modern Man, New York: The Dial Press, 1946.

Landis, Paul, Your Narriage and Family Living, New Yorkt MeGraw Hill Book Co., 1946.

Mental Health in the Classroom, Department of Supervisors and Directors of Instruction, Washington, D. C.: National Education Association, 1941.

Peters, Charles, Curriculum for Democratic Education, New York: MicGraw Hill Book Co., 1942.

Planning for American Youth, National Association of Secondary School Principals, Washington, D. C.: National Education Association, 1944.

Prescott, Daniel A., Emotion and The Educative Process, Washington. D. C.t American Council on Education, 1938.

Preston, George H., The Substance of Mental Health, New York: Rinehart and Company, 1943 .

Reeves, Floyd, Education for Today and Tomorrow, Cambridge: Harvard University Press, 1942.

Spafford, I., Building a Curriculum for General Education, Minneapolist University of Minnesota, 1943.

Stevenson, Elizabeth, Home and Family Life Education in Elementary Schools, New York: John Wiley and Sons., 1946.

Stiles, Dan, High Schools for Tomorrow, New York: Harper Bros., 1946.

The American High School, Eighth Year Book of the John Dewey Society, New York: Harper Bros., 1946.

What the High Schools Ought to Teach, Special Comittee of the Secondary School Curriculum, Washington, D. C.: American Council on Education, 1940.

Williams, L. A., Secondary Schools for American Youth, New York: American Book Co., 1944. 


\section{B. PERIODICALS}

Bane, Lita, "Whither Bound?" Journal of Home Economics, 36.1-4, January, 1944.

Brown, Clara, "Horse Economics in Postwar Education," Journal of Home Economics, 36:461, December, 1943 .

Brown, Sarah Ann, "Course in Relationships," Journal of Home Economics, 35:461, December, 1943.

Browne, Hazel M., "Teaching Good Buymanship in High Schools," Journal of Home Economics. 35:142, March, 1943 .

Cuber, John F. and Ray, Mark, "Reflections on Sex Education in the High Schools," Marriage and Family Living, Journal of the National Conference on Family Relations, 1946.

Harmsworth, Harry, "Primary Group Relations in Modern Society," Sociology and Social Research, Narch - April, 1947. p. 291.

Kirkendall, Lester A., "Sex Education in Nine Cooperating High Schools" Clearing House, 18:387-91, 457-60, March, April, 1944 .

Kirkendall, Lester A., "Straight Talks on Sex Education," Clearing House, 18:7, September, 1943.

Pritchard, Nargaret, "Home Arts in a Unified Art Program," School Review, 53.538-44, November, 1945 .

Rockwood, I. D., "Trends in Family Life Research," Journal of Home 34:647, November, 1942 .

Spicer, Niildred, "Home Making Geared to Family Living," Journal of Home Economics, 34r327, April, 1942.

Van Deusen, Mary, "Helping Young Poople Solve Their Froblems," Journal of Home Economics, 36:209, April, 1944 .

Wilson, Ione E., "Wose Job Is It?" Journal of the National Educational Association, 36:201, December, 1945. 


\section{PAMPHLFTS}

Consumer Education Study, National Association of Secondary School Principals, Learning to Use Advertising, Consumer Education Series, Unit No. 2, 1945.

Consurner Education Study of National Association of Secondary School Principals, Time in Your Hands, Consumer Education Series, Unit No. 3 , 1945.

Guenberg, Benjamin, How Can We Teach About Sex?, Public Affairs Committee Pamphlet No. 122, 1946. 